CASE REPORT

\title{
Massive localized lymphedema: A case series and literature review
}

\author{
Robin James Evans MD FRCSC, Chris Scilley MD FRCSC
}

\author{
RJ Evans, C Scilley. Massive localized lymphedema: A case series \\ and literature review. Can J Plast Surg 2011;19(3):e30-e31.
}

A large, deep, soft tissue mass is often malignant in nature; however, a recent study described a large soft tissue mass present in morbidly obese patients that was found to be benign. Massive localized lymphedema (MLL) is a large pedunculated lymphadematous mass found in the lower extremity of morbidly obese patients. MLL often enlarges over many years and may interfere with mobility. Although histologically similar to welldifferentiated liposarcoma, MLL has recently emerged as a separate, benign clinical entity. The pathophysiology of MLL is yet to be understood. A literature review, and the authors' experiences are discussed to assist in clinical decision making.

Key Words: Liposarcoma; Lymphedema; Massive localized lymphedema; Obesity; Soft tissue tumour

$\mathrm{Al}_{\mathrm{F}}$ arge, deep, soft tissue mass is often malignant in nature. However, Farshid and Weiss (1) recently described a large soft tissue mass present in morbidly obese patients that was found to be benign. Massive localized lymphedema (MLL) is a clinically and histologically distinct lesion. Clinically, MLL presents as a large pedunculated mass in a lymphedematous lower extremity; it slowly enlarges over many years. The overlying skin often exhibits induration and a peau d'orange appearance, consistent with chronic lymphedema. The mass is painless, and often the only presenting complaint is interference with gait.

MLL is similar to well-differentiated liposarcoma (WDL) because of the prominent interlobular fibrous septae that travel through the adipose tissue. Few lesions mimic liposarcoma clinically, grossly or microscopically (2). However, similar to a reactive process, the mass also exhibits thickened epidermis, lymphangiectasia and expansion of the dermis. MLL most typically exhibits floridly reactive skin and soft tissue changes.

We present our experience with this lesion and briefly summarize the existing literature to assist in clinical decision making.

\section{CASE PRESENTATIONS}

Case 1

A 44-year-old morbidly obese women was seen in consultation for a left leg mass with overlying wart-like lesions and skin thickening that had been progressively growing for many years without investigation. She was admitted for contralateral leg cellulitis during the initial consultation. The mass measured $26.2 \mathrm{~cm} \times 22.2 \mathrm{~cm} \times 19.3 \mathrm{~cm}$ (sagittally, transversely and anteroposteriorly) by ultrasound. The nature of the mass was described as a heterogenous edema. A contrast computed tomography scan also noted an abnormal soft tissue density with prominent vasculature. A decision was made to excise the lesion. There were no surgical complications, and the wound was closed. The mass itself weighed $2720 \mathrm{~g}$, and was pathologically consistent with changes secondary to chronic lymphedema.

\section{Case 2}

A 44-year-old, $260 \mathrm{~kg}$ women presented with a large pendulous mass overlying her right groin (Figure 1). Reportedly, the mass had been growing over the past six years, and was interfering with gait. The

\section{Un lymphœdème massif localisé : une série de cas et une analyse bibliographique}

\begin{abstract}
Une masse grosse et profonde de tissus mous est souvent de nature maligne, mais une étude récente a décrit la présence d'une grosse masse de tissus mous de nature bénigne chez des patients ayant une obésité morbide. Le lymphœdème massif localisé (LML) est une grosse masse lymphœdémateuse pédonculée présente sur les membres inférieurs de patients ayant une obésité morbide. Il grossit souvent en l'espace de plusieurs années et peut nuire à la mobilité. Même s'il est histologiquement similaire à un liposarcome bien différencié, le LML a récemment émergé comme une entité clinique bénigne distincte. La physiopathologie du LML n'est pas encore comprise. Une analyse bibliographique et les expériences des auteurs sont exposées pour contribuer à la prise de décision clinique.
\end{abstract}

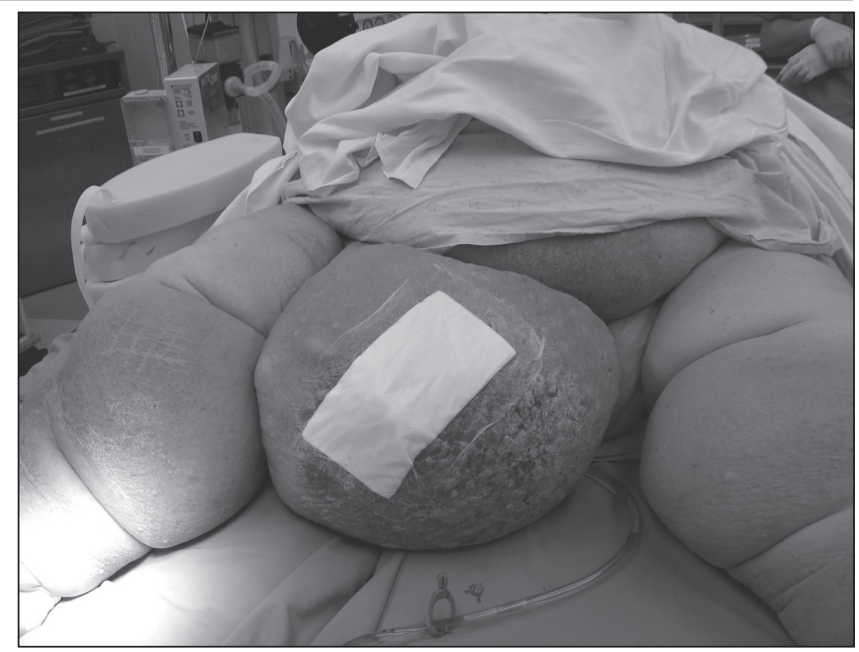

Figure 1) Massive localized lymphedema on upper medial thigh

lesion was excised (Figure 2), and the resulting wound was closed without complication. The mass measured $60 \mathrm{~cm} \times 60 \mathrm{~cm} \times 15 \mathrm{~cm}$ and presented with a peau d'orange appearance with multiple ulcers. The overlying skin was somewhat hyperpigmented with areas of hyperkeratosis.

\section{DISCUSSION}

MLL is a distinct clinical entity that has received little attention in the literature. Currently, there are five published case series/reports that include a total of 23 patients (Table 1). Farshid and Weiss (1) believe that this is due to a large number of lesions misdiagnosed as WDL. Histologically, the expanded interlobular septae mimic WDL; however, grossly reactive lesions in the context of chronic lymphedema without rapid growth implies a benign process, which is supported by skin changes related to chronic lymphedema. We believe that many lesions are diagnosed as benign, without being labelled as MLL. A common simple diagnosis would be chronic lymphedema.

Division of Plastic Surgery, Department of Surgery, University of Western Ontario, London, Ontario

Correspondence: Dr Chris Scilley, London Health Sciences Centre - Victoria Campus Room E2-214, 800 Commisioners Road East,

PO Box 5010, London, Ontario N6A 5W9. Telephone 519-667-6755, fax 519-667-6627, e-mail cscilley@uwo.ca 
The distinguishing clinical characteristic of MLL is morbid obesity. All reported MLL cases occurred in morbidly obese individuals, with an overall mean weight of $205 \mathrm{~kg}$ (Table 1). The majority of patients were women, and MLL most frequently presented on the medial thigh. Some gradual recurrence of MLL was noted in the literature, but was not noted in our patients due to the short follow-up period.

Although the clinical presentation is understood, the pathogenesis of MLL is currently unknown. Of course, lymphedema is usually considered to be caused by obstruction or obliteration of efferent lymphatic flow. Theoretically, there is a change in the lymphatic drainage secondary to a large abdominal pannus. However, Wu et al (2) suggested that the additional component of localized ischemia plays a role in the development of MLL. Usually, epidermal hypertrophy occurs because of the proliferation of keratinocytes, adipocytes and myofibroblasts secondary to the accumulation of interstitial and lymphatic fluid. It is hypothesized that growth factors are present within the edema fluid itself. However, Wu et al (2) suggests the weight and tension of the tissue may create an ischemic microenvironment and stimulate a wound-like process that recruits growth factors to the area. Ischemia then hypothetically plays a direct role in fibrosis and accentuation of the lobular structure of the fat.

Some association has been proposed between MLL and hypothyroidism. Myxedema is often an early sign of hypothyroidism and is caused by humoral and cellular immune stimulation of fibroblasts and production of a large amount of glycosaminoglycans (3). It is believed to be most often localized to the pretibial area because of its relative dependant position. In patients with MLL, the mass itself becomes the dependant area. Certainly this corresponds to the higher proportion of MLL in the lower extremity. There are two reported cases in the literature regarding hypothyroid patients with MLL (2). Some reports suggest as high as $80 \%$ of patients with lymphedema have hypothyroidism (4). Certainly hypothyroidism may play a role in the multifactorial development of MLL.

MLL is a recently described entity in morbidly obese patients that could be misdiagnosed as a neoplasm. Direct excision confirms the diagnosis and alleviates functional problems associated with the large mass. Additional research is required to understand the pathophysiology of MLL.

\section{REFERENCES}

1. Farshid G, Weiss S. Massive localize lymphedema in the morbidly obese: A histologically distinct reactive lesion simulating liposarcoma. Am J Surg Path 1998;22:1277-83.

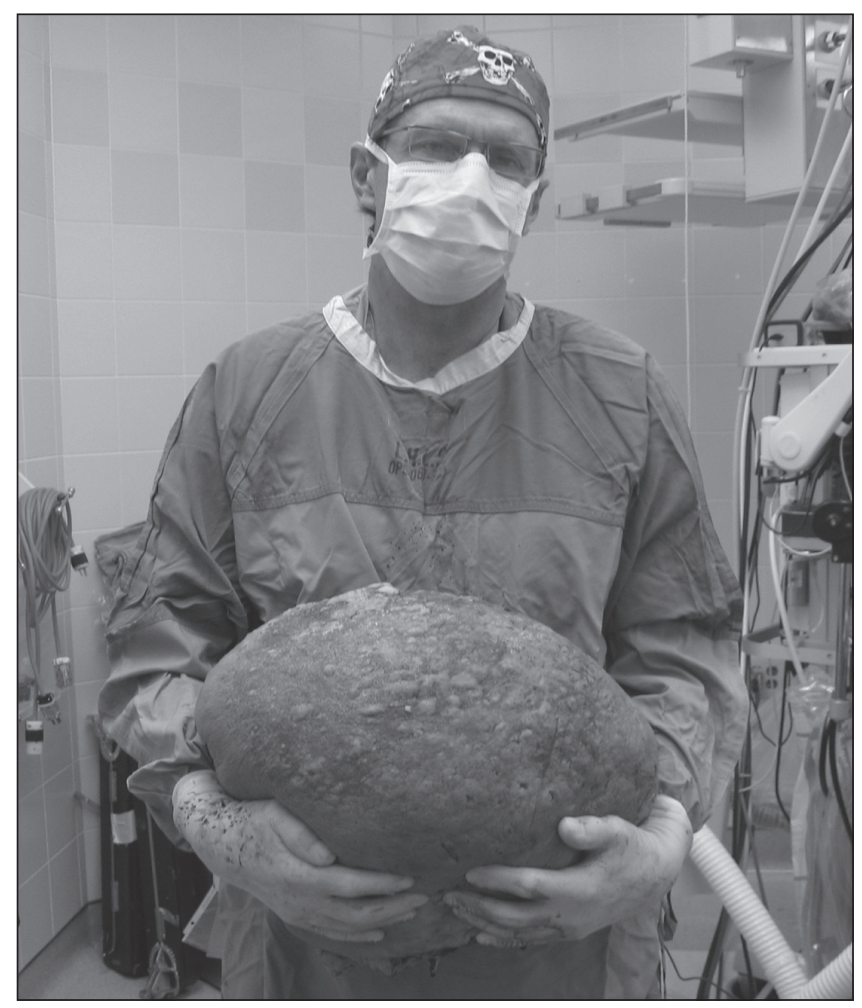

Figure 2) Massive localized lymphedema after excision

2. Wu D, Gibbs J, Corral D, et al. Massive localized lymphedema: Additional locations and association with hypothyroidism. Human Pathology 2000;31:1162-8.

3. Fatourechi V. Pretibial myxedema: Pathophysiology and treatment options. Am J Clin Dermatol 2005;6:295-309.

4. Iurkevich NP, Savchenko TV. Lymphedema and hypothyroidism. Klinicheskais Meditsina 1994;72:33-6.

5. Weston S, Clay CD. Unusual case of lymphedema in a morbidly obese patient. Aust J Dermatol 2007;48:115-9.

6. Barr J. Massive localized lymphedema of suprapubic origin. Plast Reconstr Surg 2000;106:1663-4.

7. McCrystal DJ, O'Loughlin BS. Massive localized lymphedema of the thigh. ANZ J Surg 2007;77:91-2.

TABLE 1

\section{Literature summary}

\begin{tabular}{|c|c|c|c|c|c|c|c|c|}
\hline Author (reference) & Year & Patients, n & $\begin{array}{c}\text { Mean age, } \\
\text { years }\end{array}$ & Female, \% & $\begin{array}{l}\text { Mean body } \\
\text { weight, kg }\end{array}$ & $\begin{array}{l}\text { Mean mass } \\
\text { weight, } g\end{array}$ & $\begin{array}{c}\text { Time to presentation, } \\
\text { years }\end{array}$ & Most common site \\
\hline Farshid and Weiss (1) & 1998 & 14 & 47 & 56 & 169 & 6727 & $1-10$ & Medial right thigh \\
\hline Wu et al (2) & 2000 & 6 & 47 & 67 & 212 & 6764.5 & 2.9 & Medial right thigh \\
\hline Weston and Clay (5) & 2007 & 1 & 57 & 100 & 230 & Not excised & 5 & Medial right thigh \\
\hline Barr (6) & 2000 & 1 & 76 & 100 & Not reported & Not reported & 4 & Pubic region \\
\hline McCrystal and O'Loughlin (7) & 2007 & 1 & 41 & 100 & 210 & 3000 & 3 & Medial left thigh \\
\hline
\end{tabular}

